Redaksjonelt

\title{
Et kunnskapsløft for kunnskapssamfunnet?
}

\section{En artikkelgruppe om Kunnskapsløftet}

ADNO presenterer her en artikkelgruppe om skolereformen Kunnskapsløftet som springer ut av et forprosjekt i forskningsprogrammet Utdanning 2020 (NFR) med Erling Lars Dale og Sølvi Lillejord som prosjektledere. Therese Nerheim Hopfenbeck og Sølvi Lillejord har vært setteredaktører for denne artikkelgruppen. Vi takker våre dyktige skandinaviske fagfeller for godt arbeid i prosessen med å ferdigstille artiklene for publisering.

Forprosjektets tittel er Utdanningsteori om samfunnets utdanningssystem (Educational theory about society's educational system). Tematisk tar prosjektet sikte på å analysere sammenhenger mellom samfunnsforandringer og utdanningsreformer. Bakgrunnen for prosjektet er at Norge nå - i likhet med andre land - utfordres av forventninger som følger i kjølvannet av omleggingen fra et industri- til et kunnskapssamfunn. Vi har for lengst akseptert at det må arbeides på andre måter i samfunn hvor produksjonen er kunnskapsintensiv og i mindre grad basert på råvarer. Det har imidlertid fått mindre oppmerksomhet at denne omleggingen også har store konsekvenser for utdanningssystemet og måten man organiserer seg og arbeider med kunnskap på i skolen og i høyere utdanning.

Sentralt i forprosjektet står utdanningsforskning som er gjennomført i tilknytning til Utdanningsdirektoratets program om evaluering av Kunnskapsløftet 2006-2012. Et av målene i forprosjektet var vitenskapelig formidling fra de ulike prosjektene som ble gjennomført i Kunnskapsløftet - fra ord til handling. Denne artikkelgruppen representerer derfor en realisering av et av forprosjektets mål: å publisere vitenskapelige artikler basert på Utdanningsdirektoratets oppdragsforskning i tilknytning til evalueringen av Kunnskapsløftet 2006-2012.

Reformen Kunnskapsløftet ble lansert for å følge opp sider ved Reform '94 og L '97 som politikerne mente ikke var godt nok ivaretatt gjennom implementeringen av reformene. I rundskriv F-13/04: "Dette er Kunnskapsløftet. Kultur for læring” står det: "Målet med reformen er at det beste i grunnopplæringen i Norge ivaretas og utvikles videre - slik at elever og lærlinger settes bedre i stand til å møte kunnskapssamfunnets utfordringer (s. 3).”Disse ambisjonene skal man innfri blant annet ved å formulere tydeligere mål, styrke elevenes grunnleggende ferdigheter og satse på bedre tilpasset opplæring. Nye læreplaner som utformes under Kunnskapsløftet bygger på kompetansemål, og i reformintensjonene understrekes skolens profesjonelle ansvar for å se til at man når disse målene. Sentralt i det profesjonelle arbeidet står systematiske samtaler og koordinering mellom de aktørene som er involvert i opplæringen (elever, foreldre, lærere, skoleledere og skoleeier samt det eksterne støttesystemet). De skal i fellesskap 
kunne utnytte sitt lokale handlingsrom til å sikre elevene optimalt læringsutbytte.

\section{Fra systemskifte til systemutfordring}

Som rettighets-, struktur- og kompetansereform førte Reform '94 til store forandringer i videregående opplæring. Kunnskapsløftets ambisjon var å videreføre kompetansedelen av reformen ved å vektlegge innholdskvaliteten. Grunnlaget for Kunnskapsløftet ble lagt gjennom Kvalitetsutvalgets arbeid som resulterte i de to utredningene Førsteklasses fra første klasse (NOU, 2002:10) og I første rekke: Forsterket kvalitet i en grunnopplcering for alle (NOU, 2003:16). Dette arbeidet la premissene for Stortingsmelding nr. 30 (2003-2004): Kultur for lcering, en melding som erklærte et nødvendig systemskifte og signaliserte stor tro på sektorens evne til fornyelse og forbedring om bare målene er tydelig formulert og de lokale aktørene får frihet og blir vist tillit.

Noen få år senere var det ikke lenger systemskifte, men systemutfordring som ble diskutert i policydokumentene. Systemutfordringen som var avdekket omtales slik i Stortingsmelding nr. 31 (2007 - 2008): Kvalitet i skolen: "Gapet mellom det staten forventer, og sektorens evne til å realisere disse forventningene er en systemutfordring som den enkelte lærer eller rektor ikke kan møte alene, men som skoleeierne sammen med nasjonale myndigheter må ta tak i” (s. 61). Troen på sektorens evne til å takle utfordringene i Kunnskapssamfunnet og implementere reformen Kunnskapsløftet ble nå erstattet med en storstilt satsing på kompetanseheving i form av etter- og videreutdanning. Nødvendigheten av å styrke den lokale ledelsen og ansvarliggjøre skoleeier ble understreket, og skoleledelse ble plukket ut som område for særlig innsats (Lillejord, 2011).

De fire artiklene som vi her presenterer tar hver for seg og til sammen opp sentrale sider ved reformen Kunnskapsløftet. Tematisk spenner de fra hvordan man skal styre og lede arbeidet med å utvikle elevenes grunnleggende ferdigheter i skolen, til hvordan skolene balanserer spesialundervisning og tilpasset opplæring; samt problemstillinger knyttet til gjennomføring og frafall i videregående opplæring. Et perspektiv som går igjen som en rød tråd i artiklene, er den systemutfordringen som ble beskrevet i Stortingsmelding nr. 31 (2007-2008): Kvalitet i skolen, nemlig hvordan samhandlingen er mellom nivåene og i hvilken grad lærere, skoleledere og skoleeiere faktisk har den kompetansen som er nødvendig for å implementere de politiske intensjonene og få til gode praktiskpedagogiske handlinger i opplæringen.

\section{Kort om artiklene}

Et funn som går igjen i alle de fire artiklene vi presenterer, er at vi har en systemutfordring som henger sammen med uklarheter i styringslinjen.

I den første artikkelen: ”Møtet mellom skolens profesjonsforståelse og Kunnskapsløftet som styringsreform" analyserer Jorunn Møller, Eli Ottesen og Frøydis Hertzberg (Universitetet i Oslo) to sentrale sider ved Kunnskapsløftet 
som reform: de grunnleggende ferdighetene og kvalitetsvurdering. Det dreier seg om to arbeidsfelt som ideelt sett må ses i sammenheng. Studien baserer seg på intervjuer med rektorer og en gruppe lærere ved seks grunnskoler og fire videregående skoler. Forfatterne hevder at deres materiale tyder på at reformen og skolenes arbeid med kvalitetsvurdering og grunnleggende ferdigheter ikke har medført store endringer i skolenes profesjonsforståelse:

Hvis hensikten har vært å myndiggjøre lærerprofesjonen, ser det ikke ut til at lærerne har fått tilstrekkelig informasjon til å oppfatte hvor dypt grunnleggende ferdigheter griper inn i de enkelte fagene eller hvordan det nasjonale systemet for kvalitetsvurdering kan bidra til å styrke lærerarbeidet. Den politiske styringen ser også ut til å ha vært for svak; rektorene og lærerne i vårt materiale opplever ikke at disse forventningene er blitt kommunisert til dem.

Forfatterne peker videre på at et særlig funn i deres studie er at det finnes uavklarte spenninger mellom på den ene siden politisk og profesjonell styring, og på den andre siden mellom sentral (nasjonal) og desentralisert (lokal) styring av grunnopplæringen. Dette skaper, på den ene siden, spenninger mellom tillit til profesjonen og erfaringsbasert skjønn, og på den andre siden standardiserte målinger, tilsyn og kontroll. Forfatterne hevder at profesjonen ikke synes å utnytte det handlingsrommet som Kunnskapsløftet har tilbudt. Dermed strammes også det nasjonale grepet med rapporteringskrav og veiledninger som de profesjonelle forventes å skulle følge. Møller, Ottesen og Hertzberg konkluderer slik i sin artikkel:

I Kunnskapsløftet som styringsreform ligger det til dels motstridende politiske målsettinger, ambisjoner og verdier. I vår analyse har vi identifisert flere spenninger $\mathrm{i}$ styringen av skolen. Et særlig funn er at det er uavklarte spenninger mellom på den ene siden politisk og profesjonell styring, og på den andre siden mellom sentral og desentralisert styring av grunnopplæringen, mellom nasjonal styring og lokalt selvstyre. Dette manifesterer seg i brytninger mellom tillit til profesjonen og det erfaringsbaserte skjønnet på den ene siden, og mer standardiserte målinger, tilsyn, rapportering og kontroll på den andre siden. Slike motstridende politiske målsettinger danner en kompleks ramme rundt læringsarbeidet i skolen.

At vi har utfordringer knyttet til uklarhet i styringslinjen, blir også påvist i den neste artikkelen: "Spesialundervisning i videregående opplæring fra reform 94 til Kunnskapsløftet”. Her drøfter Eifred Markussen (NIFU) praktisering og resultater av spesialundervisningen i Norge de siste 15 årene og påpeker at uklare styringssignaler fører til en uensartet praksis. Gjennom en dokumentanalyse viser han blant annet at NOU 2003:16 I første rekke anbefalte mindre spesialundervisning. Argumentasjonen som ble lagt til grunn i denne meldingen var at selv om Norge bruker store beløp på spesialundervisning, har ikke innsatsen hatt den ønskede effekt. Av juridiske årsaker fikk imidlertid ikke denne innsikten konsekvenser for Kunnskapsløftet. Markussen hevder at Regjering og 
Storting likevel kommuniser at det fra politisk hold var ønskelig med mindre spesialundervisning, noe som kunne oppfattes som doble signaler for skoler og pedagoger. Med henvisning til en tidligere artikkel publisert i adno.no (Jenssen \& Lillejord, 2009), hevder Markussen at slike uklare signaler kan bidra til at aktører opplever at de kan velge praksis selv. Uklare styringssignaler fører til en uensartet praksis, og man får store forskjeller innad i skoler og mellom skoler.

I den tredje artikkelen "Valg og gjennomføring av videregående opplæring før Kunnskapsløftet” diskuterer Eifred Markussen utfordringene knyttet til at om lag tre av ti i hvert årskull slutter før tida eller gjennomfører uten å bestå i alle fag. Basert på analyser av et stort datamateriale hevder forfatteren at grunnskolen og videregående opplæring stadig reproduserer sosial ulikhet. Dette påviser han gjennom analyser som viser at rekrutteringen til yrkesfaglige henholdsvis studieforberedende utdanningsprogrammer så vel som utfallet av videregående opplæring påvirkes av fire sett med forhold:

... de unges prestasjonsnivå fra grunnskolen, de unges faglige og sosiale engasjement med skolen, deres sosiale bakgrunn og de ulike kontekster utdanningen foregår innenfor. Prestasjonsnivået fra grunnskolen er sterkt påvirket av sosial bakgrunn. Dermed har sosial bakgrunn både direkte og indirekte effekt på kompetanseoppnåelse fra videregående opplæring.

Det samme perspektivet ble påvist i en rapport fra Birkelund, Hermansen og Evensen (2010) og aktualiserer debatten om det som nå skjer i den videregående opplæringen. Jo høyere karakterer fra grunnskolen, jo større sannsynlighet for at elever søker seg inn på en studieforberedende linje og at de også presterer faglig bedre enn elever med lavere karakterer. På samme måte spiller foreldrenes bakgrunn inn: jo høyere utdanning foreldrene har, jo bedre gjør den unge det i videregående opplæring. Forfatteren konkluderer derfor med at ungdommens sosiale bakgrunn avgjør utdanningsvalg og mulighet for å gjennomføre. Det påvises også fylkesvise forskjeller som er verdt å merke seg, og dessuten forskjeller tilknyttet kjønn og majoritets/minoritetselever som utfordrer skoleforskere og lærere i den videregående skole. Her har Markussen påpekt en rekke utfordringer som Kunnskapsløftet foreløpig ikke har maktet å løse.

Petter Aasen (Høgskolen i Vestfold og NIFU) og Nina Sandberg (NIFU) har i sin artikkel "Hvem vet best? Om styringen av grunnopplæringen under Kunnskapsløftet” beskrevet reformen og det de mener er et varslet systemskifte som ikke kom. Med utgangspunkt i nasjonale reformdokumenter, intervjuer og surveyundersøkelser har forfatterne studert sentrale aktørers rolle i arbeidet med å implementere Kunnskapsløftet. Hva kjennetegner den nye rolle -og ansvarsfordelingen og hvordan stiller skoleeier seg til den nye reformen? Analyser av surveydataene tyder på at rundt halvparten av kommunene oppfattet at det er en uklar ansvars - og rollefordeling i sektoren. Dette er mer fremtredende i tonivåenn trenivåkommuner. Analyser fra intervju avdekket også usikkerhet knyttet til hvem skoleeier er og hvilke roller de har, noe som fører til forvirring i forholdet 
mellom sentralt, statlig nivå og fylkeskommunale og kommunale skoleeiere. Aasen og Sandberg peker på at selv om nasjonale politiske reformdokumenter framstiller skoleeier som en viktig brikke i gjennomføringen av reformen, avdekker studien at skoleeierbegrepet er diffust og uklart. Dette ser ut til å få konsekvenser som forfatterne beskriver slik:

Når aktører i sentrale posisjoner på nasjonalt nivå ikke oppfattet at reformen innebærer en ny styringsstruktur, er det derfor ikke overraskende at skoleeiere heller ikke knytter myndighetsdelegering til styringsreformen.

At mandatet oppleves uklart synes å være et av de kritiske punktene ved innføringen av Kunnskapsløftet som reform. Et annet område som trekkes fram av forfatterne, er en lite tilfredsstillende dialog mellom sentralt og lokalt nivå. Skolenivået savner tydeligere signaler fra skoleeiere og nasjonalt nivå i forhold til hvordan Kunnskapsløftets ulike elementer tenkes å virke sammen for å styre og styrke kvaliteten i skolen (Møller, Prøitz og Aasen, 2009). Forfatterne påpeker at kommunale skoleeiere nå er i den uheldige situasjon at de har manglende tillit både fra skolenivå og statlig nivå.

\section{Kunnskapssamfunnet - spesielle utfordringer for Norge?}

De fire artiklene som er presentert i denne artikkelsamlingen peker på noen felles utfordringer i det videre arbeidet med Kunnskapsløftet, og det dreier seg i hovedsak om uklarheter og usikkerhet hos de ulike aktørene i systemet. Det er ikke alltid like enkelt å identifisere hva uklarhetene består i og hva de skyldes. Det kan selvfølgelig handle om utydelig styringslinje, dobbeltkommunikasjon, uklare (eller implisitte) forventninger, eller uklar ansvarsplassering. Basert på artiklene i dette temanummeret, er det imidlertid grunn til å anta at noe av forklaringen kan være av språklig art. Når ansvaret ikke blir kommunisert tydelig nok, fanges det heller ikke alltid opp av de som skal ta det. Hvis stortingsmeldinger og NOU'er har et abstrakt og idealisert språk, kan dette føre til at gapet mellom idealene og realitetene virker uoverskridelig for de som skal sette de politiske ideene ut i praksis. Når omtalen av praksis befinner seg på et ideelt og normativt plan, blir det rett og slett vanskelig for praktikerne å vite hva de skal gjøre. Vi tror at dette er et lite utforsket område i norsk utdanningsforskning.

I en nylig publisert rapport fra OECD, The Nature of Learning, antyder også Istance og Dumont (2010) at språket er en utfordring i forhold mellom forskning, politikkutforming og praksisfeltet:

Far too often, research is addressing problems or is produced in formats and language which cannot be applied by those working in education. But equally, in a world where increasingly policy and practice are meant to be "evidence-informed" (even if to be "evidence-based" may be largely out of reach given education's sheer complexity), there is need to take much more seriously the evidence on the nature of learning as 
covered in this volume. It should be used to help redesign learning environments and to inform policy programmes aimed at raising educational quality and equity.

Det kan være grunn til å spørre om denne kompleksiteten er underkommunisert også i Norge når forskningsresultater skal formidles til praksisfeltet via policydokumenter.

Til sammen tegner artiklene et bilde av at vi befinner oss i en situasjon hvor skolereformen Kunnskapsløftet mangler et perspektiv på spesielle utfordringer i kunnskapssamfunnet. Et problematisk forhold er at policydokumentene verken påpeker, drøfter eller analyserer hvilke spesielle utfordringer utdanningssektoren har i overgangen til en ny samfunnsformasjon. Policydokumentene bruker "Kunnskapssamfunnet" i likhet med "lærende organisasjon” og tilsvarende betegnelser som innholdstomme begrep. De rommer alt og ingenting. Politikken formuleres dessuten i et fremmedgjørende (abstrakt og idealisert) språk som er så fjernt fra praksis at praktikerne blir rådville og opplever at de mangler nødvendig handlingsberedskap. I tillegg er styringslinjen uklar og det rår usikkerhet lokalt i forhold til hvem som er ansvarlige for hva, hva man har ansvar for og hvordan ansvaret skal skjøttes. Vi har med andre ord et implementeringsproblem i deler av norsk utdanningsvesen, og det er viktig å identifisere mer spesifikt hva dette problemet består i.

Når det gjelder økonomisk og sosial velferd ligger Norge godt an, sammenlignet med andre land. Utdanningsnivået i befolkningen er også høyt. Vår globale konkurranseevne antas imidlertid å være avhengig av en stadig bedre utdannet befolkning hvor utvikling og oppdatering av avansert kompetanse representerer selve ryggraden i samfunnet. Kunnskap om hvordan dette skal skje antas å bli en konkurransefaktor i kunnskapssamfunnets utdannings- og arbeidsliv. I forprosjektet Utdanningsteori for samfunnets utdanningssystem blir det lagt til grunn at den viktigste nøkkelkompetansen i dagens kunnskapssamfunn er ”å lære å lære”. Denne nøkkelkompetansen kan vi (for analytiske formål) anta består av tre deler:

a) Akademisk kunnskap og kompetanse som kommer til uttrykk gjennom de grunnleggende ferdighetene (lesing, skriving, regning osv.)

b) Sosial kompetanse (mellommenneskelig forståelse og relasjonsferdigheter som for eksempel omgjengelighet).

c) Kunnskaper om samfunn, makt og samfunnsstrukturer (ferdigheter som trengs for demokratisk medborgerskap og samfunnsutvikling).

I sin analyse av den norske middelklassens kunnskapssyn finner Skarpenes og Sakslind (2010) at de som tilhører middelklassen i Norge både er ambivalente i spørsmål om klasseidentifikasjon og at de har en "remarkable tendency to downplay the importance of education” (s. 219). Når det gjelder å positivt verd- 
sette utdanning og den kunnskap utdanningssystemet gir den enkelte, skiller vi oss i vesentlig grad negativt ut i forhold til land vi ellers gjerne sammenligner oss med. I Norge verdsettes praksiskunnskap høyere enn akademisk kunnskap. Når vi nå ikke bare står på terskelen til Kunnskapssamfunnet, men har den ene foten godt plassert innenfor, er det nødvendig at vi ser grundigere på hvordan vi som nasjon verdsetter utdanning og den formen for kunnskap vi får gjennom det formelle utdanningssystemet. Hva vi kommuniserer til barn og unge om betydningen av utdanning har konsekvenser for hvordan de senere velger å forholde seg til skole og studier.

\section{Uklarhet og systemutfordring}

Mens det kan se ut som om Norge strever med uklarheter i sitt styringssystem uklare forventninger, uklar ansvarsplassering, uklart språk - viser en OECD rapport fra 2007 (Hargreaves mfl., 2007) et helt motsatt bilde av Finland, som arbeider systemisk (helhetlig) med pedagogiske forbedringstiltak. I følge rapporten ikke bare føler ledere på alle nivåer ansvar - de tar også ansvar for alle elevenes læring. Alle som arbeider i utdanningssektoren, det vil si i skolen, i kommunen og i skolens støttesystem, blir innprentet at det er en felles oppgave å gi den enkelte elev best mulig oppfølging og bidra til å forbedre og fornye skolens pedagogiske praksiser når det er nødvendig. En finsk skoleleder har for eksempel ikke bare ansvar for den skolen han eller hun leder, men for hele skoledistriktet. Ansvaret for prestasjoner og forbedringstiltak i området er dermed kollektivt, og alle må ta sin del av veiledning og oppfølging av den enkelte skole. Fordi systemet bygger på et prinsipp om gjensidig avhengighet og støtte, kommer de lengst med å stille opp for hverandre.

I stedet for å tro at mennesker er avhengige av eksternt press for å yte sitt beste, legger finnene til grunn at god kvalitet oppnår man gjennom ansvarsplassering, systematisk samarbeid og samhandling på alle nivåer i utdanningssystemet. Støttesystemene i utdanningssektoren baserer seg dermed på gjensidighet i relasjoner og kompetanseutveksling i nærmiljøet. Den finske suksessen baserer seg på evne til å se og forstå hvordan ting henger sammen og gjensidig forutsetter hverandre, og i tillegg evne til å samle seg om det som er viktig, og forene de relevante faktorene.

Det finske systemet bygger på langsiktighet og helhetstenkning, bred deltakelse, felles aksept for målene som er satt, og enighet om at alle har et ansvar for å hjelpe de som trenger det. Finnene er ikke bare fokusert på mål eller resultater, men svært opptatt av hvordan de skal få til gode prosesser. Det nytter nemlig ikke å innføre et system som baserer seg på målstyring og resultatvurdering uten samtidig å ivareta det som ligger mellom mål og resultat, nemlig prosess.

At Finland står i en særstilling, ble også påvist i forbindelse med offentliggjøring av PISA 2009 resultatene 7. desember i år. Mens $60 \%$ av de norske elevene går på en skole hvor rektorene svarer at elevresultater blir 
offentliggjort, rapporterer finske rektorer at dette forekommer svært sjelden. Ved spørsmål om elevenes faglige resultater brukes til å sammenligne egen skole med andre skoler, ligger Sverige, Island og Norge over OECD gjennomsnittet, mens Finland er det landet i Norden hvor rektorene oppgir at dette gjøres i minst grad. Forskerne skriver:

Det å bruke elevresultater til å sammenligne skolen med andre skoler og for å følge med utviklingen fra år til år vil trolig være mer relevant i skolesystemer hvor det er fokus på dokumentasjon og ansvarliggjøring når det gjelder elevenes resultatoppnåelse.

(Hopfenbeck, Kjernsli, \& Throndsen, 2010)

Oppsummert vil vi si at hvis det stemmer at vi i Norge har en implementeringsutfordring, har vi også en ledelsesutfordring. God ledelse innebærer ikke bare klar ansvarsplassering, men også at man sørger for at de som arbeider i systemet, setter standarder for arbeidet sitt. Det er et profesjonelt ansvar og noe man for eksempel gjør ved å stille spørsmål som: Hva kjennetegner god undervisning og hva er godt arbeid i skolen? Først når man har utviklet standarder eller kjennetegn og vet hvordan man skal arbeide fram mot målene, er man i posisjon til å nå målene. De fire empiriske undersøkelsene vi presenterer i dette artikkelgruppen i adno.no og analysene av datamaterialet, bidrar til å utvide vår forståelse av den systemutfordringen som ble påpekt i Stortingsmelding nr. 31 (2007-2008). Vi påpeker også mulige nye forskningsspørsmål som kan øke vår innsikt i hvilke særlige utfordringer vi har i Norge når nye reformer skal implementeres.

Oslo, desember 2010

Sølvi Lillejord, Therese Nerheim Hopfenbeck og Erling Lars Dale

\section{Litteratur}

Birkelund, G. E., Hermansen, A. S. \& Evensen, Ø. (2010). Skolesegregering - et problem? Elevsammensetning, frafall og karakterer. (s. 98). Oslo: Institutt for sosiologi og samfunnsgeografi.

Hargreaves, A., Halász, G. \& Pont, B. (2007). School leadership for systemic improvement in Finland. A case study report for the OECD activity Improving school leadership. Paris: OECD.

Hopfenbeck, T. N., Kjærnsli, M. \& Throndsen, I. (2010). Rektorenes svar på spørsmål i skolespørreskjemaet. I M. Kjærnsli, \& A. Roe (Red.), På rett spor (178 - 192). Oslo: Universitetsforlaget.

Istance, D. \& Dumont, H. (2010). Future direction for learning environments in the 21st century. I H. Dumont, D. Istance, \& F. Benavides (Red.), The Nature of Learning Using Research to Inspire Practice (318 - 338). Paris: OECD. 
Jenssen, E. S. \& Lillejord, S. (2009). Tilpasset opplæring: politisk dragkamp om pedagogisk praksis. Acta Didactica Norge 3(1), 15 sider. Hentet fra http://adno.no/index.php/adno/article/view/99/131

Lillejord, S. (2011). Kunsten å være rektor. I J. Møller, \& E. Ottesen (Red.), Rektor som sjef og leder. Om styring, ledelse og kunnskapsutvikling i skolen. Oslo: Universitetsforlaget.

NOU. (2002:10). Førsteklasses fra første klasse. Forslag til rammeverk for et nasjonalt kvalitetsvurderingssystem for norsk grunnopplering.

NOU. (2003:16). I første rekke. Forsterket kvalitet i en grunnopplering for alle.

Skarpenes, O. \& Sakslind, R. (2010). Education and Egalitarianism: the culture of the Norwegian middle class The Sociological Review 58(2), 219 - 243.

Stortingsmelding. (2003-2004). Kultur for læring (Nr. 30): Kunnskapsdepartementet.

Stortingsmelding. (2007-2008). Kvalitet i Skolen (Nr. 31). Oslo: Kunnskapsdepartementet. 